\title{
Analysis of the Condyle, Articular Fossa and Mandibular Ramus in Subjects with Active Condylar Hyperplasia
}

\author{
Análisis del Cóndilo, Fosa Articular y Rama Mandibular \\ de Sujetos con Hiperplasia Condilar Activa
}

Pablo Muñoz; ${ }^{*}$ Douglas Rangel Goulart ${ }^{* * *}$; Sergio Olate ${ }^{* * * * * * * *}$; Márcio de Moraes ${ }^{* * *}$; Pablo Navarro* \& Rodrigo Fariña ${ }^{* * * * * *}$

MUÑOZ, M; GOULART, D. R.; OLATE, S.; DE MORAES, M.; NAVARRO, P. \& FARIÑA, R. Analysis of the condyle, articular fossa and mandibular ramus in subjects with active condylar hyperplasia. Int. J. Morphol., 32(3):1064-1068, 2014.

SUMMARY: Facial asymmetry is relatively common, but it becomes a disease when condylar hyperplasia is involved. The purpose of this investigation was to describe and compare the morphological characteristics of hyperplastic condyles to their nonhyperplastic contralateral side. Fifteen subjects aged between 14 and 29 years with facial asymmetry and diagnosed with unilateral condylar hyperplasia were studied using cone-beam computerized tomography. Linear measurements were taken of the condylar morphology on the sagittal and coronal planes, establishing the size of the articular fossa, mandibular ramus, and other aspects. Sagittal condylar measurements showed significant differences $(\mathrm{p}=0.028)$ between the groups (hyperplastic side v/s non-hyperplastic side); ramus measurements showed significant differences $(\mathrm{p}=0.034)$ between the two sides. No significant differences were observed $(\mathrm{p}=0.155)$ in the relation of the mean lateral distance (coronal image) of hyperplastic and non-hyperplastic condyles. It can be concluded that there is an increase in the size of the hemimandible and TMJ on the hyperplastic side, although research with a greater number of patients is needed to establish a more precise trend.

KEY WORDS: Facial asymmetry, condylar hyperplasia, facial deformity

\section{INTRODUCTION}

Facial asymmetry is a relatively common condition, with prevalence from $21 \%$ to $85 \%$ in different populations (Baek et al., 2012). It has also been shown that true facial symmetry is rare, where subjects accepted as symmetrical usually present variations between the two sides of the face (Ferrario et al., 1994). In cases where the facial asymmetry is greater than $5 \mathrm{~mm}$ (measured from the midline) and is perceived by people without medical and dental knowledge (Naini et al., 2011), the patient's search for surgical solutions becomes more frequent.

In hyperplasia, the number of cells increases while the size of the cells themselves does not. In the mandibular condyle, hyperplasia presents at different stages of life (Nitzan et al., 2008), taking on a variety of morphologies, all of which manifest an increase in the size of condyle, causing the jaw to deviate towards the contralateral side to a greater or lesser degree (Nitzan et al., 2008). It has been reported that almost $30 \%$ of facial asymmetries may be related to unilateral condylar hyperplasia (UCH) (Olate et al. 2013a).

Wolford et al. (2014) reported that condylar hyperplasia could present bilaterally, although there is as yet no consensus on this point. However, it is entirely possible for condylar hyperplasia to present in both $\mathrm{TMJ}$, since if the normal growth of an anatomical structure is known, it is feasible to understand when an increase in the number of cells occurs.

Bilateral hyperplastic growth of the mandibular condyle has not been confirmed, but there is a consensus that $\mathrm{UCH}$ can be established when both condyles are compared by bone scintigraphy, which must generate differences of at least 10\% in the uptake of the injected isotope (Olate et al., 2013a).

* Program of Master in Dental Science, Dental School, Universidad de La Frontera, Temuco, Chile.

** Division of Oral and Maxillofacial Surgery, State University of Campinas, Piracicaba, Brazil.

*** Division of Oral and Maxillofacial Surgery \& CEMYQ, Universidad de La Frontera, Temuco, Chile.

***** Center for Biomedical Research, Universidad Autónoma de Chile, Temuco, Chile.

****** Department of Oral and Maxillofacial Surgery, Universidad de Chile, Santiago, Chile. 
Abnormal condylar growth in $\mathrm{UCH}$ causes a recognizable facial asymmetry. Previous studies have shown that the increase in condylar size generates significant displacement of the chin towards the contralateral side, which can cause significant functional and esthetic alterations (Nitzan et al., 2008). Generally, the growth of UCH is fast, triggering significant occlusal alterations and consequently other anatomical alterations of the craniomaxillofacial area, although these have not been entirely quantified.

The aim of this research was to establish the morphology of the condyle with $\mathrm{UCH}$ and its relation to the articular fossa and mandibular ramus, comparing it with the side without condylar hyperplasia.

\section{MATERIAL AND METHOD}

This study was conducted in the Division of Oral and Maxillofacial Surgery of the Universidad de La Frontera and its protocol was approved by the university's Research Ethics Committee under protocol 066/13. All the patients agreed voluntarily to participate in the study.

Fifteen subjects aged between 14 and 29 years with a facial asymmetry associated with UCH were studied by cone beam computerized tomography (CBCT) (PlanMeca®, Korea). Inclusion criteria included patients having a clinical diagnosis of mandibular asymmetry with a chin deviation greater than 5 $\mathrm{mm}$ from the midline, analysis with CBCT, and SPECT imaging, where the difference in the uptake of the isotope Tc $99 \mathrm{~m}$ had to be higher than $10 \%$. Excluded were all subjects who, although they presented all the positive patterns for UCHassociated facial asymmetry, also had other facial alterations such as previous facial trauma, surgery for a maxillofacial pathology, previous orthognatic surgery, or other issues.

All the images were obtained using the same equipment, which was operated by two previously trained technicians. The images were analyzed with the EZ3D plus software (2009) by a single observer on three different occasions 15 days from the initial measurement in order to reduce statistical error.

In the coronal and sagittal images observed on the monitor, the following measurements were taken:

Condylar width (sagittal): Sagittal resections were taken every $3 \mathrm{~mm}$, once the condyle was recognized, moving from lateral to medial. The widest part of the condyle was determined (one posterior point and another anterior) and the measurement was taken in $\mathrm{mm}$.
Condylar width (coronal): Coronal resections were taken every $3 \mathrm{~mm}$, once the condyle was recognized, moving from anterior to posterior. The widest part of the condyle was determined (one medial point and another lateral) and the measurement was taken in $\mathrm{mm}$.

Condylar length (sagittal): Sagittal resections were taken every $3 \mathrm{~mm}$, and the best image corresponding to the sigmoid notch was determined to establish the vertical distance from the condylar neck to the head. 1) A line was drawn from the lowest point of the notch, perpendicular to the posterior edge of the mandibular ramus, 2) the measurement was taken from the highest point of condyle to the previously mentioned lower line passing through the central area, determining the length of the condylar neck and head ( $\mathrm{mm})$.

Width coronoids (sagittal): Sagittal resections were taken every $3 \mathrm{~mm}$, and the coronoid process was determined, going from lateral to medial. The widest sector of the coronoid process was established (one point more posterior and another more anterior) and the measurement was taken in $\mathrm{mm}$.

Length of coronoids: Sagittal resections were taken every $3 \mathrm{~mm}$, and the best image corresponding to the sigmoid notch and coronoid process was determined. From the line below the previously drawn sigmoid notch, the vertical line was established in the central area, which extended to the superior vertex of the coronoid process. Distance was measured in $\mathrm{mm}$.

Length of ramus: Sagittal resections were taken every $3 \mathrm{~mm}$, and the best image corresponding to the mandibular ramus and body was determined. The distance was recorded from the highest point of the condylar head parallel to the posterior edge of the mandibular ramus down to the lowest point of the mandibular angle.

Height of eminence: Sagittal resections were taken every $3 \mathrm{~mm}$, and the best image corresponding to the articular eminence, articular fossa and mastoid process was established. From the highest point of the fossa a horizontal line was drawn parallel to the horizontal line drawn from the lowest point of the articular eminence. The distance between the two parallels was established through a perpendicular line, the distance of which was measured in $\mathrm{mm}$.

Depth of fossa: From the superior central point of the articular fossa, a straight line was drawn downwards that intersected with the line produced between the lowest point of the articular eminence and the lowest point of the mastoid process. The distance was measured in $\mathrm{mm}$. 


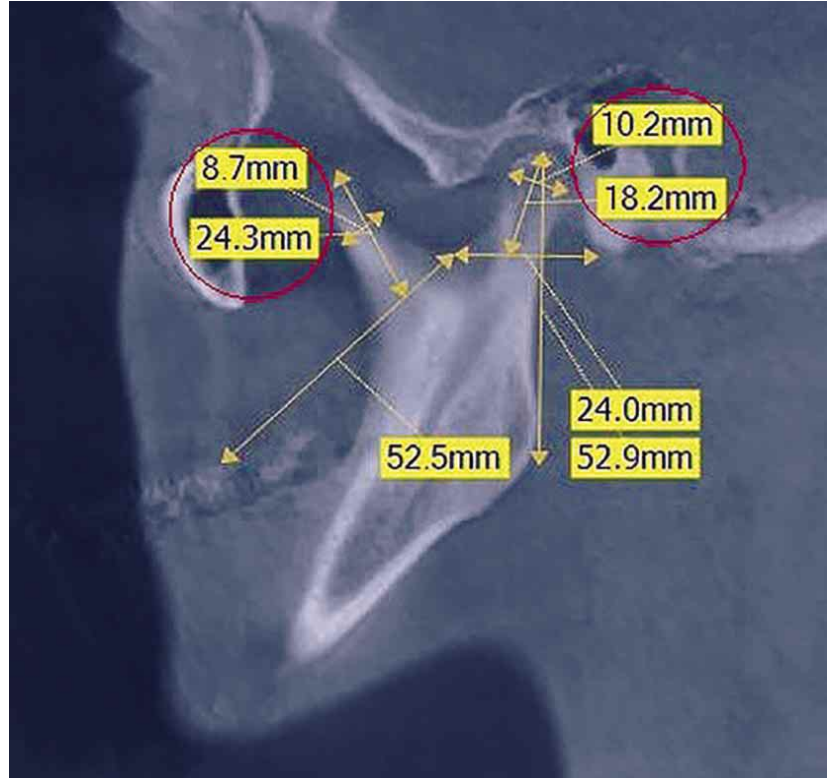

Fig. 1. Sagittal measurements taken on the condylar process and the coronoid process.

The variables were analyzed by studying the side with UCH and the side without condylar hyperplasia. The ttest for related samples, two-way ANOVA and analysis of agreement through the intraclass correlation coefficient (ICC) were used for the data analysis. The software SPSS 20.0 was used, and the level of significance for each test was considering $\mathrm{p}<0.05$.

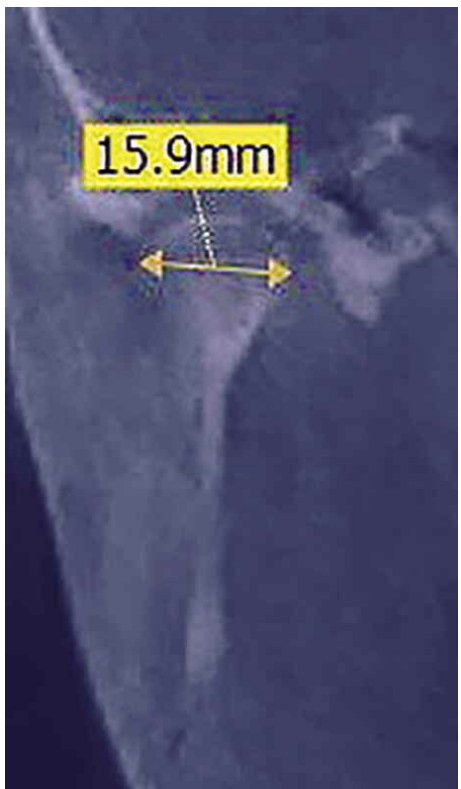

Fig. 2. Coronal measurements taken on the head of the mandibular condyle. All measurements were bilateral.

\section{RESULTS}

A total of 15 subjects, 7 male (46.7\%) and 8 female (53.4\%) with an average of age of 20.1 years (range 14-29 years) were analyzed in this study (Table I). 7 subjects were affected by $\mathrm{UCH}$ on the left side $(46.7 \%)$, the remaining 8 on the right side $(53.4 \%)$.
Table I. Distribution of the 15 patients analyzed in this investigation and their general characteristics

\begin{tabular}{|c|c|c|c|c|c|}
\hline \multirow{2}{*}{ Patient } & \multirow{2}{*}{$\mathbf{n}$} & \multicolumn{2}{|c|}{ Age } & \multicolumn{2}{|c|}{ Hyperplastic Condyle } \\
\hline & & $<20$ years & $>20$ years & Left & Right \\
\hline Male & 7 & 5 & 2 & 4 & 3 \\
\hline Female & 8 & 6 & 2 & 3 & 5 \\
\hline Total & 15 & 11 & 4 & 7 & 8 \\
\hline
\end{tabular}

The study was conducted with no alterations to the proposed protocol. The collected data showed average values that are shown in Table II.

A. Condylar relations: The sagittal condylar measurements showed significant differences

Table II. Average of measurements taken and the statistical result for each measurement in the 15 subjects included in the study.

\begin{tabular}{lccc}
\hline Measurements & $\begin{array}{c}\text { Hyperplastic side } \\
\text { X } \pm \text { SD }\end{array}$ & $\begin{array}{c}\text { Non-hyperplastic side } \\
\text { X } \pm \text { SD }\end{array}$ & $\boldsymbol{p}$ \\
\hline Condylar width (sagittal) & $9.32 \pm 1.61$ & $8.70 \pm 1.43$ & $0.028^{*}$ \\
Condylar width (coronal) & $16.67 \pm 2.34$ & $13.83 \pm 2.52$ & 0.445 \\
Condylar length (head and neck) & $18.74 \pm 4.16$ & $17.89 \pm 3.64$ & 0.126 \\
Width of coronoid process & $7.08 \pm 1.40$ & $6.83 \pm 1.08$ & 0.099 \\
Length of coronoid process & $15.99 \pm 3.34$ & $16.96 \pm 3.09$ & 0.348 \\
Length of ramus & $64.06 \pm 6.82$ & $61.16 \pm 5.38$ & $0.034^{*}$ \\
Height of articular eminence & $8.15 \pm 2.02$ & $8.22 \pm 1.77$ & 0.230 \\
Depth of articular fossa & $14.33 \pm 1.49$ & $13.64 \pm 1.96$ & 0.182 \\
\hline
\end{tabular}

$\mathrm{X}=$ average; $\mathrm{SD}=$ standard deviation; $*$ = positive statistical significance. 
$(\mathrm{p}=0.028)$ between the study groups (comparison between condylar hyperplasia and condylar non-hyperplasia). However, no significant differences were observed for the coronal condylar measurements $(\mathrm{p}=0.445)$. Likewise, there were no significant differences in the measurements of condylar length $(\mathrm{p}=0.126)$. Another interesting finding was that no significant differences were observed in the depth of the articular fossa $(\mathrm{p}=0.155)$.

B. Mandible relations: The results of the sectorial analyses showed no significant differences in the height of the articular eminence $(p=0.230)$. In the analyses of the coronoid process, no significant differences were observed in terms of its height $(\mathrm{p}=0.348)$ and its width $(\mathrm{p}=0.099)$. The measurements taken to establish the vertical range of the mandibular ramus showed significant differences between the two sides $(\mathrm{p}=0.034)$.

\section{DISCUSSION}

$\mathrm{UCH}$ is a disease known in its general aspects. Usually there are facial asymmetries which are difficult to resolve if not detected early (Nitzan et al., 2008). Morphological studies have enabled a better understanding of the function of the condyles in the genesis of facial asymmetries, being associated in some cases to increased or decreased growth (Olate \& de Moraes, 2012; Mizoguchi et al., 2013).

Saccucci et al. (2012a, 2012b) reported that subjects presenting a reduced mandibular size frequently have small mandibular condyles, whereas when the condylar size is increased, there is also an increase in mandibular size. These findings have led to the conclusion that the mandibular condyles play an important role in the growth and development of the maxillofacial area and may be directly associated with the patient's maxillomandibular characteristics (Rodrigues et al., 2009a, 2009b).

Previous studies into condylar hyperplasia have shown that the size of the hyperplastic condyle is statistically greater than the non-hyperplastic condyle (Olate et al., 2013a), contrasting with the results obtained here, which show only significant differences in the sagittal analysis. This condition may be linked to the type of measurement or to the fact that the subjects in this study presented pathologies in an early stage. Olate et al. (2013a) indicated that the increase in condylar size might be related to the degree of facial asymmetry, establishing some criteria to be used in the diagnostic analyses of patients (Zapata et al., 2014).
One interesting finding in this study is that the depth of the articular fossa and the height of the articular eminence do not present significant differences between the two condyles, which makes it possible to establish that the entire anatomical environment adapts to the alteration in condylar size; in other words, a larger condyle demands a larger fossa, a condition that our results were able to confirm.

In addition, the height of the mandibular ramus presented significant differences between the hyperplastic and non-hyperplastic side. Given that in this study there were no differences in the vertical distance from condylar neck to head, it may be assumed that the differences in the vertical height of the mandibular ramus are precisely in the part below the sigmoid notch, showing the impact of the growth of the whole hyperplastic sector.

Elongations of the mandibular ramus have also been determined by studies analyzing class III subjects (Kim et al., 2013), which may suggest that the hyperplastic condyle and the entire affected side grow by behaving like the growth of a condyle in a class III skeletal pattern, which might confirm that condylar hyperplasia presents a class III behavior in terms of its condylar and skeletal morphology. You et al. (2010) showed that as hyperplastic mandibular condyles grow, so the mandibular ramus and body grow greater than the contralateral side, which is significantly associated with our results. Variations in bilateral condylar size are associated with changes in mandibular angle (Saccucci et al., 2012a), so that unilateral increased growth would generate mandibular growth in equal proportion unilaterally.

Condylar morphology has an impact on facial morphology, determining the patient's skeletal characteristics (Nitzan et al., 2008; Olate et al., 2013b). The presentation of condyles with hyperplasia allows the simultaneous growth of the articular fossa to achieve adaptation of the growing condyle, which suggests an established craniomandibular growth pattern and not only an exponential and spontaneous growth of the mandibular condyle; it also suggests a coordinated and sequential growth of the sector with condylar hyperplasia.

This study raises more questions than it answers. It is possible to conclude that there are differences in some parameters when variables of sectors with and without condylar hyperplasia are compared. Nevertheless, the majority of the variables in this study did not present significant differences. Investigations with a greater number of patients are needed to establish more precise trends. 
MUÑOZ, M; GOULART, D. R.; OLATE, S.; DE MORAES, M.; NAVARRO, P. \& FARIÑA, R. Análisis del cóndilo, fosa articular y rama mandibular de sujetos con hiperplasia condilar activa. Int. J. Morphol., 32(3):1064-1068, 2014.

RESUMEN: La asimetría facial es relativamente común, transformándose en enfermedad cuando se asocia hiperplásia condilar. El objetivo de esta investigación fue describir y comparar las características morfológicas de los cóndilos hiperplásico con su contralateral no hiperplásico. Quince sujetos de entre 14 y 29 años de edad, con asimetría facial e hiperplasia condilar unliateral diagnosticada, fueron estudiados mediante tomografía computarizada Cone-Beam. Se determinaron mediciones lineales de la morfología condilar en vista coronal y sagital, estableciendo tamaños de la fosa articular, rama mandibular, entre otras. Las mediciones condilares sagitales mostraron diferencias significativas $(\mathrm{p}=0,028)$ entre los grupos (lado hiperplásico vs. lado no hiperplásico); las mediciones de longitud de rama mostraron diferencias significativas $(\mathrm{p}=0,034)$ entre ambos lados. No se observó diferencias significativas $(\mathrm{p}=0,155)$ en la relación de distancia medio lateral (imagen coronal) de cóndilos hiperplásico y no hiperplásicos. Concluimos que existe un aumento del tamaño hemimandibular y de la ATM del lado hiperplásico, aunque investigaciones con mayor número de pacientes son necesarios para establecer una tendencia mas exacta.

PALABRAS CLAVE: Asimetría facial; Hiperplásia condilar; Deformidad facial.

\section{REFERENCES}

Baek, C.; Paeng, J. Y.; Lee, J. S. \& Hong, J. Morphologic evaluation and classification of facial asymmetry using 3-dimensional computed tomography. J. Oral Maxillofac. Surg., 70(5):1161-9, 2012.

Ferrario, V. F.; Sforza, C.; Poggio, C. E. \& Tartaglia, G. Distance from symmetry: a three-dimensional evaluation of facial asymmetry. J. Oral Maxillofac. Surg., 52(11):1126-32, 1994.

Kim, H. O.; Lee, W.; Kook, Y. A. \& Kim, Y. Comparison of the condyle-fossa relationship between skeletal class III malocclusion patients with and without asymmetry: a retrospective three-dimensional cone-beam computed tomography study. Korean J. Orthod., 43(5):209-17, 2013.

Mizoguchi, I.; Toriya, N. \& Nakao, Y. Growth of the mandible and biological characteristics of the mandibular condylar cartilage. $J$. Dent. Sci. Rev., 49(4):139-50, 2013.

Nitzan, D.; Katsnelson, A.; Bermanis, I.; Brin, I. \& Casap, N. The clinical characteristics of condylar hyperplasia: experience with 61 patients. J. Oral Maxillofac. Surg., 66(2):312-8, 2008.

Olate, S.; Cantín, M.; Alister, J.; Uribe, F.; Navarro, P.; Olate, G. \& de Moraes M. Relationship Between Condylar Size and Transverse Facial Asymmetry in Subject with Condylar Hyperplasia. Int. J. Morphol., 31(3):937-41, 2013a.

Olate, S.; Almeida, A.; Alister, J. P.; Navarro, P.; Netto, H. D. \& de Moraes, M. Facial asymmetry and condylar hiperplasia: considerations for diagnosis in 27 consecutives patients. Int. J. Clin. Exp. Med., 6(10):937-41, 2013 b.

Olate, S. \& de Moraes, M. Asymmetric Facial Deformity. Role of Condylar Hyperplasia. Int. J. Odontostomat., 6(3):337-47, 2012.

Rodrigues, A. F.; Fraga, M. R. \& Vitral, R. W. Computed tomograph evaluation of the temporomandibular joint in class I malocclusion patients: Condylar symmetry and condyle-fossa relationship. Am. J. Orthod. Dentofacial Orthop., 136(2):192- 8, 2009a.
Rodrigues, A. F.; Fraga, M. R. \& Vitral, R. W. F. Computed tomograph evaluation of the temporomandibular joint in class II división 1 and class III malocclusion patients: Condylar symmetry and condyle-fossa relationship. Am. J. Orthod. Dentofacial Orthop., 136(2):199-206, 2009b.

Saccucci, M.; Polimeni, A.; Festa, F. \& Tecco S. Do skeletal cephalometric characteristics correlate with condylar volume, surface and shape? A 3D analysis. Head Face Med., 8(15):1- 8, 2012a.

Saccucci, M.; D’Attilio, M.; Rodolfino, D.; Festa, F.; Polimeni, A. \& Tecco, S. Condylar volume and condylar area in class I, class II and class III young adult subjects. Head Face Med., 8:34, 2012b.

Tecco, S.; Saccucci, M.; Nucera, R.; Polimeni, A.; Pagnoni, M.; Cordasco, G.; Festa, F. \& Iannetti, G. Condylar volume and surface in Caucasian young adult subjects. BMC Med. Imaging, 10:28, 2010.

Wolford, L. M.; Movahed, R.; Perez, D. E. A classification system for conditions causing condylar hiperplasia. J. Oral Maxillofac. Surg., 72(3):567-95, 2014.

Zapata, S.; Medina, H.; Saravia, D.; Navarro, P. \& Olate, S. Morphometric Analysis of the Mandible in Patients with Facial Asymmetry Associated to Condylar Hyperplasia. A Panoramic Radiography Study. Int. J. Morphol, 32(1):161-5, 2014.

\section{Correspondence to:}

Prof. Sergio Olate, PhD

Division of Oral and Maxillofacial Surgery

Universidad de La Frontera

Claro Solar 115, Of. 414-A

Temuco - CHILE

Email: sergio.olate@ufrontera.cl

Recibido : 19-04-2014

Aceptado: 22-06-2014 